\title{
The Improvement in Poetry Writing Skills by Using Prezi in the Primary School
}

\author{
Atika Susanti ${ }^{1}$, Ali Mustadi², Asnimar ${ }^{3}$ \& Esti Susiloningsih ${ }^{4}$ \\ 1,2 Pendidikan Dasar, Pascasarjana, Universitas Negeri Yogyakarta \\ 3,4 Prodi Pendidikan Guru Sekolah Dasar, FKIP, Universitas Sriwijaya \\ $\square$ atikasusanti.2017@student.uny.ac.id
}

\begin{abstract}
Writing is one of the subjects taught at school. Through poetry writing, students' imaginative writing skills can be improved. The purpose of this research is to describe the improvement in poetry writing skills and students' activity using Prezi. This research employed a classroom action research method conducted in three cycles. Each cycle consisted of four stages, namely: planning, implementation, observation, and reflection. The subjects of this research were fifth-grade students of a primary school in Inderalaya consisting of 13 male students and 16 female students. The instrument of the data collection was a poetry writing test. The results of the three cycles in this research were $44.44 \%, 78.57 \%$, and $89.28 \%$ respectively. It showed an increase in poetry writing skills of fifth-grade primary school students after the use of Prezi media in learning. Hence, it can be concluded that Prezi was an appropriate media to teach poetry writing. It is recommended that Prezi could be used as an alternative media to teach writing in the primary school.
\end{abstract}

Keywords: poetry writing skills, Prezi, primary school, teaching media.

How to Cite: Susanti, A., Mustadi, A., Asnimar, A., \& Susiloningsih, E. (2019). The Improvement in Poetry Writing Skills by Using Prezi in the Primary School. Mimbar Sekolah Dasar, 6(1), 92-104. doi:http://dx.doi.org/10.17509/mimbar-sd.v6i1.14557.

INTRODUCTION Writing is one of the language skills that is important to be taught in formal education. Tarigan (2013, p. 2) states that writing is one of the language skills used in indirect communication in which its mastery requires training, as Zainurrahman (2013, p.7) affirms that the scope of writing skills is very broad and requires accuracy in using punctuation, language structure, word selection, and writing format mastery. Furthermore, Anae (2014, p. 123) states that the important point of writing is the imaginative activity, while the learning process supports activities to explore the imagination.
Writing skills are significant to be taught in school. Nugroho (2014, p. 24-25) believes that writing can be a catharsis, which is a process of releasing emotions and tension; and increasing the body's immunity because storytelling through writing can reduce the psychological life burden. Accordingly, Leo (2010, p. 2-3) reveals that writing can channel expertise, healthy activities and can improve the ability to interpret the relationship, responsiveness, and student perceptions in solving problems (Astuti \& Mustadi, 2014, p. 251). Through writing, students can express feelings, opinions, and ideas and communicate them with readers. 
Atika Susanti et al., The Improvement in Poetry Writing Skills by Using Prezi...

Through poetry writing, imaginative writing skills can be enhanced. Nurgiyantoro (2016, p. 312) opines that poetry is one literature genre that pays attention to linguistic aspects so that the language used also requires a word selection process. The combination of imaginative activities and diction, which have elements of sounds, forms and meanings, are carried out in such a way as to form writings that have beauty value.

Poetry writing skills are significant to be taught in formal school, hence, writing poetry materials are included in the primary school curriculum, designed for fifth grade students. In the 2013 Curriculum, these materials have been listed in the Basic Competency (KD/Kompetensi Dasar) point 4.4, stating that "To independently sing and present rhymes and poem about natural disasters, and the life of nation and state in spoken and written forms in Bahasa Indonesia by selecting and sorting vocabulary standard". It means that every student must master writing poetry skills as the curriculum output. However, its implementation still faces several obstacles.

Several studies have been conducted as an effort to improve students' poetry writing skills, such as: research conducted by Aryusmar \& Putria (2014); Utami, Djuanda, \& Aeni (2016); Putri, Ngatman, \& Joharman (2017), and others show that poetry writing skills are still a problem for elementary school students as they relatively lack of poetry writing skills.
The lack of poetry writing skills was also found in the elementary school where the research was conducted. The observation to fifth grade students showed that there were still many students who were confused and hesitant in writing poetry. Students found it difficult to imagine based on the topic given, and some were found to lacked enthusiasm. This is shown by the acquisition of learning outcomes in writing poetry that was still low. The initial test showed that 20 students (65.52\%) had not achieved mastery learning in accordance with the Minimum Completion Criteria (KKM, Kriteria Ketuntasan Minimal) set by the school, which was 65 . There were only 10 of 29 students (34.48 \%) who passed the writing poetry test

Students' difficulty in finding vocabulary is the most problem in poetry writing. This is related to the process of vocabulary acquisition. Vocabulary acquisition activities are closely related to meaningful activities that have occurred in the past (Ritchie, Sedikides, \& Skowronski, 2016, p. 578); reading activities (Duff, Tomblin, \& Catts, 2016, p. 854); talk and listen (Dolan, 1985, p. 7). Consequently, writing learning must be associated with other language skills, like: reading, speaking, listening, and recalling students' past experiences. Thus learning strategies need to be developed to prepare the students to be ready to use media in the class.

The use of media in the learning process has an important role. Learning media is a tool used in conveying messages in 
learning (Omodara \& Adu, 2014, p. 50) to achieve learning goals (Ramdhani \& Muhammadiyah, 2015, p. 175). The use of learning media helps students in the learning process, since it has many forms and types. Aqib (2013, p. 53) states that there are three types of media, namely: visual media, audio media, and multimedia. In addition, Rusman (2013, p. 173) states that there are also audio-visual media and computer-based media. Media and technology that have been growing rapidly should have a positive impact on the learning process.

Through the use of media and technology, teachers can present various learning resources for students in the classroom (Mcknight et al., 2016, p. 7). Various media uses have also been carried out in previous research as an effort to improve students' poetry writing skills. These studies included the use of images or visual media (Jaya, R., \& Ermanto, 2013; Azmussya'ni \& Wangid, 2014); and audio media (Wahyudi \& Hariani, 2014). However, the components of media that have been used in previous studies were not used as a whole media. Therefore, this research seeks to use various forms of learning resources that can be presented in the form of one learning media. The media chosen in this research is Prezi.

Prezi was developed by Hungarian architect Adam Somlia-Fischer as an architectural visualization tool. Its mission is to "make ideas more interesting". Prezi is often compared with other popular pre- presentation media, Power Point. There are differences in how Prezi works compared to Power Point, but it gives more free space to pour creations in making presentation slides. Furthermore, Wulandari \& Hakim, $(2014$, p. 3) opine that Prezi is an alternative media that can easily display an idea in an interconnected view between slide shows. This is very helpful for students to be able to easily understand the presentation materials that are being displayed.

Prezi allows users to display content or materials linearly or non-linearly. Its zoom-in and zoom-out features and emphasis on important parts can be utilized (Strasser, 2014 , p. 96). With these advantages, Prezi can support displaying virtual media images to be presented in the classroom. The use of Prezi is considered effective in conveying important points in learning and strongly supports student-centered learning (Cunningham, 2014, p. 78). In line with these opinions, Akgün, Babur, \& Albayrak (2016, p. 8) state that Prezi's features possessed allow students to be actively involved in the learning process and can improve student learning outcomes and can improve students' language skills (Velloso, Bastos, \& Macedo, 2016, p. 70). Based on the findings of previous research, this research focuses on the use of Prezi, so the fifth grade students of elementary school can learn how to write poetry. The purpose of this research is to describe the implementation of Prezi in improving poetry writing skills of fifth grade 
Atika Susanti et al., The Improvement in Poetry Writing Skills by Using Prezi...

students of elementary school, and to describe the improvement Thus, it is expected that the use of Prezi could increase students' poetry writing skills .

\section{METHODS}

This research employed a classroom action research method using the John Elliot model. The research consisted of cycles covering four stages: planning, implementation, observation, and reflection (Arikunto et al., 2011, p. 16). This research was conducted in three cycles to see the gradual improvement in poetry writing skills of fifth grade students. The subjects in this research were 29 fifth grade students, consisting of 13 male students and 16 female students.

The implementation of learning using Prezi was done by the researcher in several stages, as follows:(1) beginning the class; (2) stating the learning outline; (3) presenting the teaching materials using Prezi (in the form of: text, images, and videos); (4) asking students to pay attention to the images displayed with Prezi; (5) displaying a sample of poetry that matches the displayed image; (6) asking students to read and understand the poetry; (7) explaining poetry writing based on the object characteristics in the picture, the poetry elements, and the poetry type: (8) displaying several images with the same theme using Prezi as students' to write poetry; (9) asking students to pay attention to the displayed images until the students fully-comprehend the images;
(10) guiding students to list as many related words as possible; (11) asking students to determine the title of their own poem; (12) asking students to start writing poems based on the listed words; (13) reviewing the lessons learned; and (14) closing the learning session

Data collection technique used in this research was poetry writing. The test was in a form of a poetry writing test. The results of the poetry writing test were assessed based on seven aspects, namely: (1) the suitability of the title of the poetry to the image (TI), (2) the suitability of the title of the poetry to the content (TC), (3) diction (D), (4) real words (RW), (5) imagination (I), (6) language style (LS), and (7) rhythm/tone (RT) (Effendy et al., 2010, p. 139-141). This observation was used to see the engagement of students in the activities during the learning process.

The data of the learning outcomes were analyzed to see the students' understanding level on the learning materials. The collected data were analyzed by quantitative data analysis technique. Data analysis was carried out since the research activities took place. The categories of students' poetry writing skills were grouped into five categories, which are: very good ( $\geq 80)$, good (65-79), good enough (50-64), poor (35-49), and bad ( 34 ). The criteria used in this research are said to be successful if the poetry writing skills of students have met the KKM which was 65 and classical completion, which was $80 \%$. 


\section{RESULTS AND DISCUSSION}

The research was conducted in three cycles in five meetings. Each of Cycle I and II were done in two meetings, while Cycle III was done in one meeting. The first meeting was about an introduction to poetry and how to write poetry by utilizing Prezi as the media. Meanwhile, the second meeting focused on the use of Prezi in helping students to write poetry and testing the progress of students' poetry writing skills.

The planning stage in the Cycle I was carried out by the researchers who involved class teachers as collaborators. The activities were analyzing curriculum, preparing lesson plans, poetry themes, Prezi, and poetry writing test. The next step was implementation. The activities in first meeting of Cycle I were: discussing types of poetry formula with the help of Prezi; asking students to work in groups to understand the types of poetry. Student activities had started to getting more difficult, although there were still some students who lack concentration in learning (initials: MI, AR, RA, BR, DS, and JS). These students often chat outside the learning materials. Nevertheless, some students had also been very active in learning when using Prezi (initials: A, MFA, PA, SU, HS, QP, RP, MRP, and F) and they were very enthusiastic about watching Prezi's shows and did question and answer with the teacher.
In the second meeting of Cycle I, there were two students absent (initials: $A E$ and SU). This second focused on giving stimulation steps to write poetry. Specifically, the teacher displayed pictures and words that were interconnected using Prezi. Prezi helped students to write poetry with the theme "My Goals".

The results of writing poetry of students in this Cycle I showed that the achievement of scores in the $\mathrm{TI}$ indicator was still very balanced and varied. This score was ranging from score 1-4. In the TC indicator, the students mostly got a score of 3 . The students' skills in writing poetry content in accordance with the title were good enough. Their difficulties in choosing diction, real words, and imagination were still very less visible in the acquisition of scores in indicators D, RW, and I. Meanwhile, MFA and RP were the only students classified in very good $D$ selection. This also applied to LS and RT indicators. Even though the positive results were shown by student HS who scored 4 in the LS indicator, most students only got the score of 1 and 2. The highest score was obtained by student $A$ with a score of 23 while the lowest score was obtained by MI with only 7 points. The acquisition of scores in each indicator of student poetry writing skills is shown in Figure 1 below. 
Atika Susanti et al., The Improvement in Poetry Writing Skills by Using Prezi...

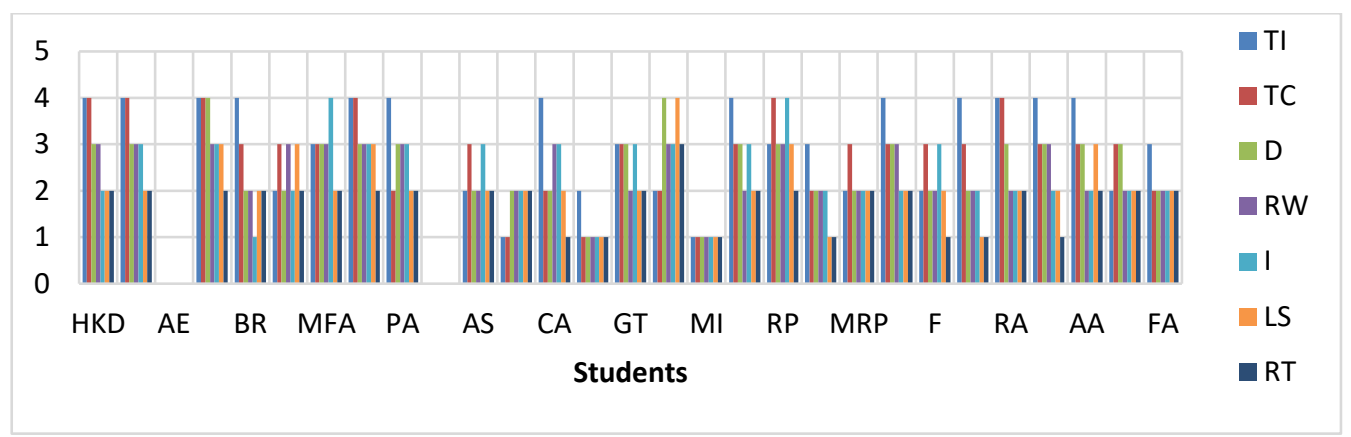

Figure 1. Results of Cycle I Poetry Writing Skills Test.

The planning activity in the Cycle II developed based on the results of Cycle I. The researcher and collaborators discussed ways to minimize students' inactivity. Therefore, in addition to themes selection, this activity also focused on the use of learning strategies. In this cycle, Scramble cooperative learning model was used with the hope that students could be actively involved in learning. The implementation of activities in the first meeting of Cycle II of was conducted by discussing poetry and elements in poetry. Based on the improvement in the Cycle I, Prezi was added with interesting videos and images so students interested in learning. In addition, during the learning, teachers asked more questions to students to avoid them chatting outside the learning materials. This time the students were asked to respond and practice reading poetry in front of the class. This effort showed positive results, most of the students were very enthusiastic in being involved in the learning process, even though there were still students, like BR, who seemed to have less participation.

The test activity was carried out in the second meeting of Cycle II. There was one student, RA, who did not attend school because of illness. The theme of the poem in Cycle II was "Public Place". The Prezi media was compiled and contained with pictures of several public places, such as: worship places, markets, and terminals. Based on these images, several related words were listed, so that students got an overview of the theme of the poetry to be written.

The test results in the Cycle II showed a very good increase in each indicator. In the $\mathrm{TI}$ indicator, most students had obtained maximum scores, even though JS still scored 2 in this cycle. This was also found in TC indicators, only JS and DS who were still having difficulty synchronizing the titles and contents of the poetry written. The number of students who scored well in indicator $D$ also increased even though there were some students who still found it difficult to find the diction to write on their poetry. The RW indicator showed that students were still having a hard time in choosing the words that will be used in writing poetry. Most of the difficulties of the students were in imagining language style and rhythm in poetry. This was shown in the acquisition of score in indicators I, LS, and 
RT. However, the skills of some students showed an increase. The number of students who got a score of 4 also increased for each indicator. Student $A$ had the best total score of 26 while student DS got the least number of scores, 12. Figure 2 below illustrates the acquisition of scores for each indicator in Cycle II.

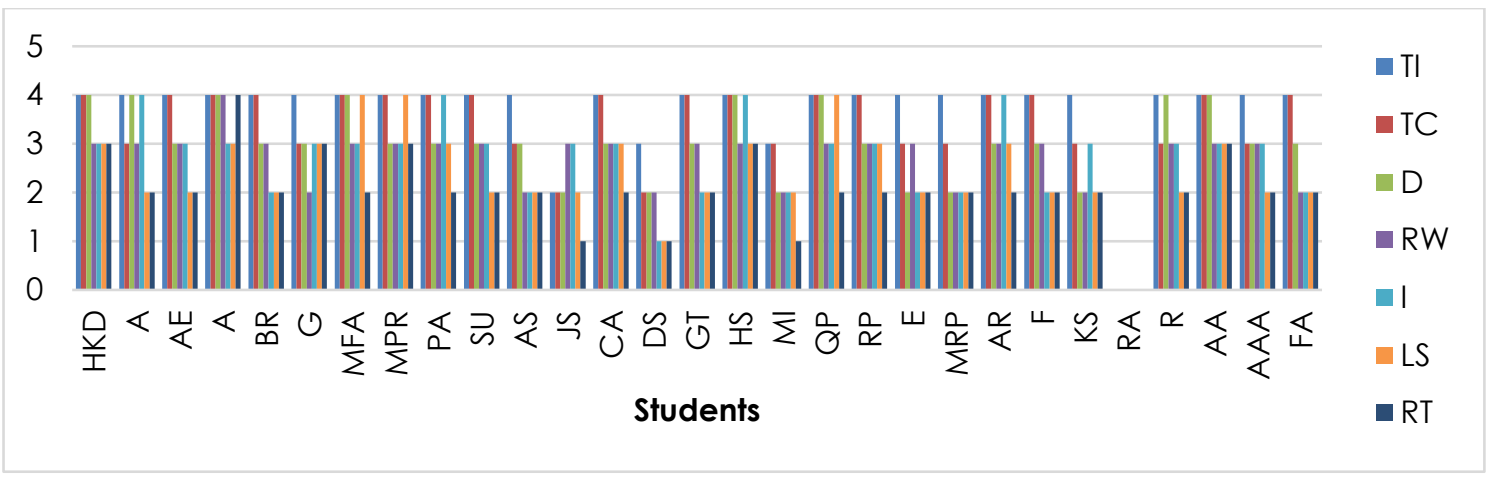

Figure 2. Results of Cycle II Poetry Writing Skills Test.

Cycle III was conducted to see the consistency of students who scored well in previous cycle. The activity directly focused on writing poetry activities. FA was not present at this meeting. The theme of writing poetry in this Cycle III was "My Family'. Prezi interactively displayed images of family members through zooming in and out of objects. Students were enthusiastic to see the shown images. The teachers tried controlling the classroom atmosphere so it more directed. The interaction of students with teachers and students with students were welldirected. Prezi attractively helped students to list words related to images. The teacher helped motivating the students to find more words related to the images.

The test results in the Cycle III showed that student scores that were relatively consistent with scores obtained in Cycle II. In the TI indicator, almost all students obtained maximum scores. Not much different from obtaining a score in the $\mathrm{TI}$ indicator, students also experienced an increase in the TC indicator. This showed that students have begun to understand the images that were displayed and the titles written and the poetry theme were more directed. In addition, students wrote the contents according to the title written. Indicators D and RW also showed that students began to be skilled in using words in poetry. Although not as good as other indicators, indicator I also experienced a fairly good increase. Students felt closeness to the poetry written. Although it can be seen that students had difficulty using LS and putting RT in poetry, but there was an increase in the indicator. The highest number of scores was still obtained by $A$ with 26 points and there were two students namely JS and DS which got the lowest score of 16 . The following Figure 3 depicts the scores for each indicator of students' poetry writing skills. 
Atika Susanti et al., The Improvement in Poetry Writing Skills by Using Prezi...

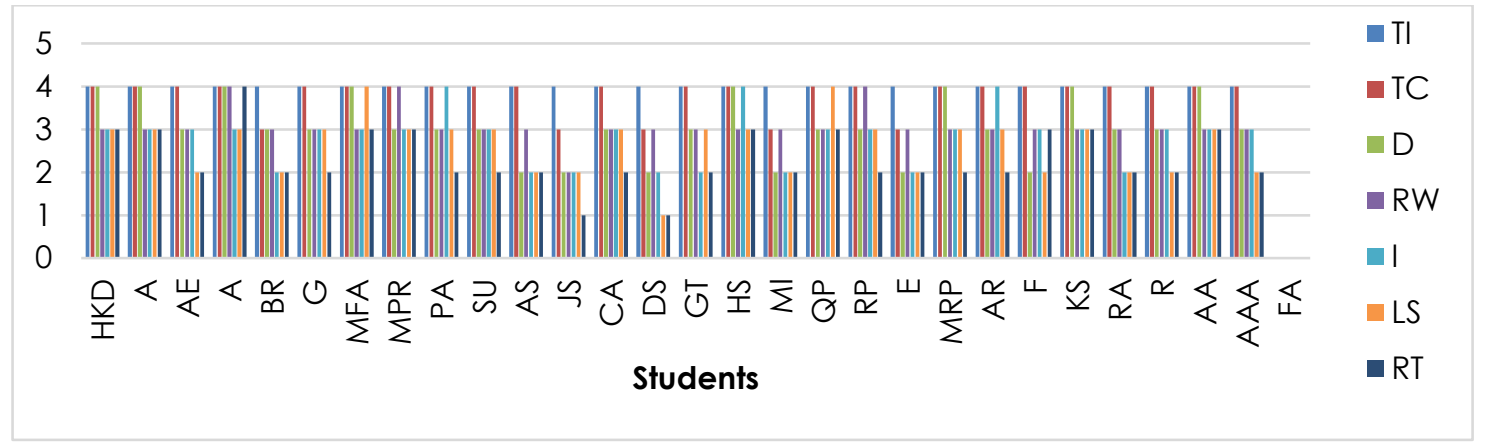

Figure 3. Results of Cycle III Poetry Writing Skills Test.

The following Figure 4 depicts the improvement of students' poetry writing skills in each cycle.

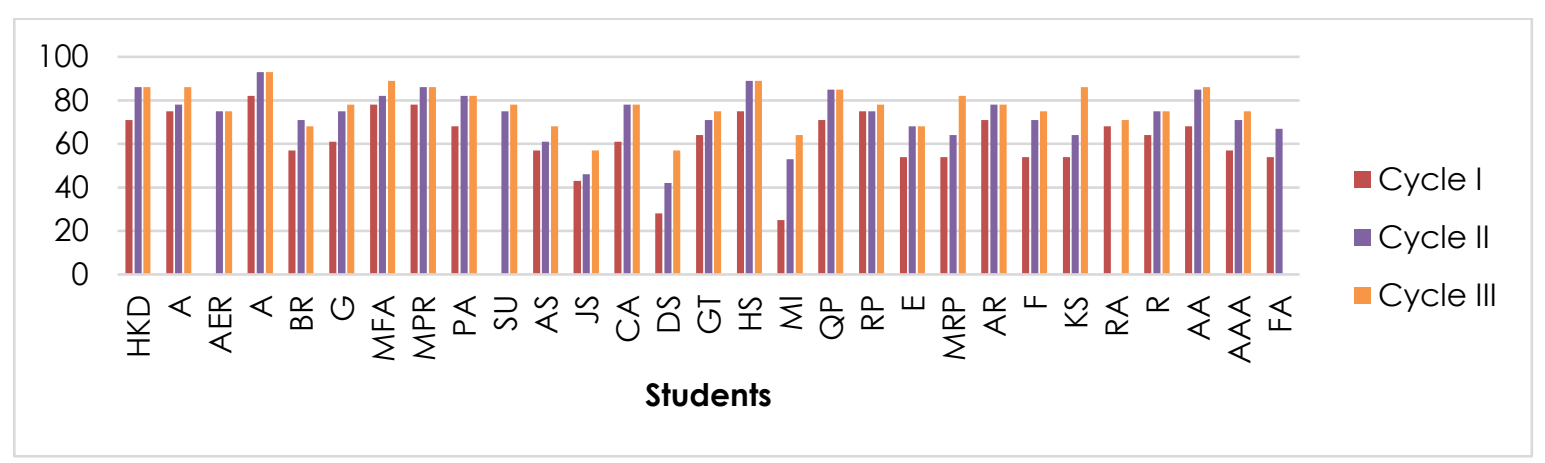

Figure 4. Results of Poetry Writing Skills Test in Cycles I, II and III.

The results of the students' poetry writing skills test in the Cycle I showed that the students who completed the learning were 12 students while the students who did not passed the learning were 15 students. Only one student who scored more than 80 and there were four students who still scored low (35-49). The test results in Cycle II showed a lot of improvement in students' poetry writing skills. This was evidenced by the increase of students who completed the learning, which were 22 students and the reduction of students who did not complete into six students. In addition, the number of students who had scored more than 80 had increased from one student to eight students and there were no more students in the less good category. It was also supported by the results of student tests in Cycle III which showed that there were 25 students who completed and only three did not complete. In addition, students who scored very well in the category increased to 12 students. After seeing the increase in the ability of poetry writing students in the Cycle III, consisted of more than $80 \%$ passed students, the classroom action research was stopped. Table 1 below shows the mapping of the test scores of students' poetry writing skills in each cycle.

Table 1. Value of Cycle I, II, and III Poetry Writing Skills.

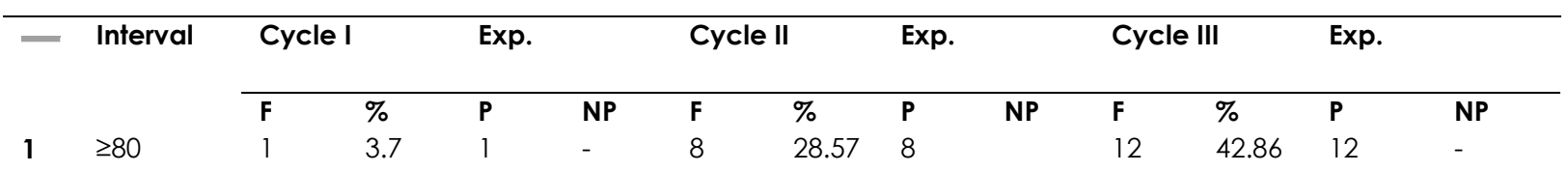




\begin{tabular}{|c|c|c|c|c|c|c|c|c|c|c|c|c|c|}
\hline \multirow[t]{2}{*}{-} & \multirow[t]{2}{*}{ Interval } & \multicolumn{2}{|c|}{ Cycle I } & \multicolumn{2}{|l|}{ Exp. } & \multicolumn{2}{|c|}{ Cycle II } & \multicolumn{2}{|l|}{ Exp. } & \multicolumn{2}{|c|}{ Cycle III } & \multicolumn{2}{|l|}{ Exp. } \\
\hline & & $\mathbf{F}$ & $\%$ & $\mathbf{P}$ & NP & $\mathbf{F}$ & $\%$ & $P$ & NP & $\mathbf{F}$ & $\%$ & $\mathbf{P}$ & NP \\
\hline 2 & $65-79$ & 11 & 40.7 & 11 & - & 14 & 50 & 14 & & 13 & 46.43 & 13 & - \\
\hline 3 & $50-64$ & 11 & 40.7 & - & 11 & 6 & 21.43 & & 6 & 3 & 10.71 & - & 3 \\
\hline 4 & $35-49$ & 4 & 14.8 & - & 4 & - & - & - & - & - & - & - & - \\
\hline 5 & $\leq 34$ & - & - & - & - & - & - & - & - & - & - & - & - \\
\hline \multicolumn{2}{|c|}{$\begin{array}{l}\text { Sum } \\
\text { Percentage (\%) }\end{array}$} & $\begin{array}{l}27 \\
93.1 \\
\end{array}$ & 100 & $\begin{array}{l}12 \\
44.44 \\
\end{array}$ & $\begin{array}{l}15 \\
55.56\end{array}$ & $\begin{array}{l}28 \\
96.55 \\
\end{array}$ & 100 & $\begin{array}{l}22 \\
78.57 \\
\end{array}$ & $\begin{array}{l}6 \\
21.43 \\
\end{array}$ & $\begin{array}{l}28 \\
96.55 \\
\end{array}$ & 100 & $\begin{array}{l}25 \\
89.28 \\
\end{array}$ & $\begin{array}{l}3 \\
10.78 \\
\end{array}$ \\
\hline
\end{tabular}

Figure 5 below depicts the completion of the results of the skills of students in Cycle I, Cycle II, and Cycle III.

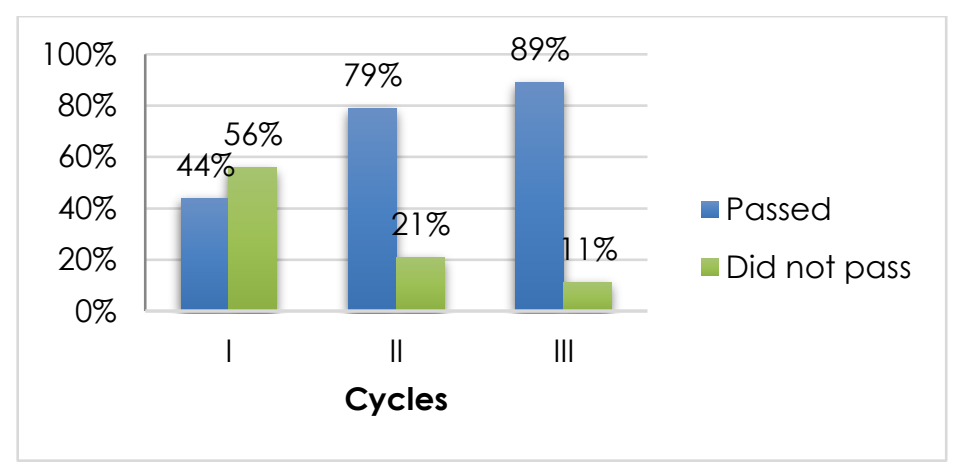

Figure 5. Completion of Results of Student Poetry Writing Skills in Cycle I to Cycle III.

Considering the percentage results, the research could be said to be successful because it had reached a predetermined indicator, which is the classical completion of students reaching more than $80 \%$. In addition, students' activity in the learning process in the classroom had also increased. Therefore, this classroom action research was sufficient and research is considered successful.

The increase in the results of increasing poetry writing skills is supported by Asyhar (2012, p. 185) stating that the use of media would highly improve the learning outcomes. The use of technology in instructional media has been proven to have a positive impact on learning. This is expressed by Figg \& Jamani (2013, p. 96) that the use of technological media in learning could improve skills in practice and technical, so that the quality of learning $w$ also increase (Sunaengsih, 2016, p. 188). In line with the opinion of Sunaengsih, Ayari, Ayari, \& Ayari (2012, p. $411)$, the use of technology in classroom learning on a practical level could draw attention to learning. The use of technology that involves more than one sense of the student could also have an impact on increasing student learning motivation (Wu \& Tai, 2016, p. 1072). This would affect the quality of learning itself. The impact of the use of learning media in the form of technology could ultimately improve the quality of the teaching process (Liu, 2016, p. 101).

The increase in the quality of teaching and the learning process would certainly have an impact on students learning outcomes. This is supported by the results of the study 
Atika Susanti et al., The Improvement in Poetry Writing Skills by Using Prezi...

of Bester \& Brand (2013, p. 12) stating that the use of technology could significantly affect the average student achievement. In this case the intended learning achievement is students' poetry writing skills. In particular, Kumar \& Sultana (2016, p. 77) stated that the use of technology as a learning media was a solution to students' problems in writing. Besides being able to solve writing problems, Lan, Hung, \& HSU $(2011$, p. 161) stated that the impact of increasing student writing attitudes could also be caused by the use of technology media in learning.

Through Prezi, students' potential can be accommodated so that the level of learning outcomes would increase as it is very effective for students in terms of knowledge acquisition (Chou, Chang, \& Lu, 2015, p. 81). One aspect of the media favored by Prezi in improving learning outcomes is multimedia, which is a combination of various media elements such as text, images, animations and videos. Taufiqurrahman, Untari, \& Yuniastuti (2013, p. 3) stated the advantages of Prezi is that it could integrate objects in the form of text, images, videos and other presentation to facilitate the audience, specifically to help students understand the contents of the presentation materials. With this advantage, Al-Hammouri (2019, p. 134) stated that the use of Prezi as a learning media could provide opportunities for students to be actively involved in learning. In addition, the advantages of Prezi slides that can be run both linearly and non-linearly allow students to review past materials and also anticipate the next materials. In line with that, Prezi's special advantage in improving poetry writing skills was stated by Aljehani (2015, p. 77), which can improve vocabulary. The number of vocabulary is certainly very helpful for students in writing poetry. Thus, the advantages of technology media in the form of Prezi both directly or indirectly can support an increase in the value of writing student poetry.

\section{CONCLUSION}

Based on the obtained research findings, the conclusions draws are: (1) Prezi could improve students' poetry writing skills. The results of writing poetry achieved by students in the implementation of the Cycle I were $44.44 \%$, in Cycle II $78.57 \%$ and Cycle III 89.28\%; (2) Prezi could increase students' involvement in the learning process. The results of students' involvement was 58.28, after some treatments, in Cycle I the score was 68.26, in Cycle II was 74.45, and in Cycle III was 85.78; (3) Prezi was suitable to be use in learning and could be an alternative for writing activities.

\section{REFERENCES}

Akgün, Ö. E., Babur, A., \& Albayrak, E. (2016). Effects of lectures with powerpoint or prezi presentations on cognitive load, recall, and conceptual learning. International Online Journal of Educational Sciences, 8(3), 1-11.

Al-Hammouri, S. (2019). The effect of using 
prezi on Al Zaytoonah University students' performance in French language reading skills. International Education Studies, 12(1), 128-135. https://doi.org/10.5539/ies.v12n1p128

Aljehani, W. M. (2015). Using prezi presentation software to enhance vocabulary learning of efl secondary school students. Educational Research International, 4(4), 67-81.

Anae, N. (2014). "Creative writing as freedom, education as exploration ": Creative writing as literary and visual arts pedagogy in the first year teacher-education experience. Australian Journal of Teacher Education, 39(8), 123-142.

Aqib, Z. (2013). Model-model, media, dan strategi pembelajaran kontekstual (inovatif). Bandung: Yrama Widya.

Arikunto, S. (2011). Penelitian tindakan kelas. Jakarta: Bumi Aksara.

Aryusmar, \& Putria, W. (2014). The effectiveness of teaching creative writing using cinquain poetry. Humaniora, 5(2), 1037-1048.

Astuti, Y. W., \& Mustadi, A. (2014). Pengaruh penggunaan media film animasi terhadap keterampilan menulis karangan narasi siswa kelas $\mathrm{V}$ SD. Jurnal Prima Edukasia, 2(2), 250262.

Asyhar, R. (2012). Kreatif mengembangkan media pembelajaran. Jakarta: Refrensi.

Ayari, M. A., Ayari, S., \& Ayari, A. (2012). Effects of use of technology on students' motivation effects of use of technology on students' motivation. Journal of Teaching and Education, 1 (2), 407-412.

Azmussya'ni, \& Wangid, M. N. (2014). Peningkatan keterampilan menulis menggunakan pendekatan proses dengan media gambar di sdn 3 Sakra. Jurnal Prima Edukasia, 2(1), 1-13. https://doi.org/10.21831/jpe.v2i1.2640

Bester, G., \& Brand, L. (2013). The effect of technology on learner attention and achievement in the classroom. South African Journal of Education, 33(2), 115.

Chou, P., Chang, C., \& Lu, P. (2015). Prezi versus powerpoint: The effects of varied digital presentation tools on students' learning performance. Computers \& Education, 91, 73-82. https://doi.org/10.1016/j.compedu.201 5.10 .020

Cunningham, C. M. (2014). Special report prezi presentational software as an educational tool for analyzing pathology slides: Promoting a learner centered environment through. Lab Medicine, 45(2), 73-79. https://doi.org/10.1309/LMSOJFCHA7D MQCOM

Dolan, M. W. (1985). Integrating listening , speaking, reading, and writing in the classroom. Language Arts Journal of Michigan, 1(1), 7-12.

Duff, D., Tomblin, J. B., \& Catts, H. (2016). The influence of reading on vocabulary growth: A case for a matthew effect. Journal of Speech, Language, and Hearing Research, 58(June 2015), 853-864. https://doi.org/10.1044/2015

Effendy, U., dkk. (2010). Sastra anak dan pembelajarannya di sekolah dasar. Indralaya: Universitas Sriwijaya.

Figg, C., \& Jamani, K. J. (2013). Transforming classroom practice: Technology professional development that works! Teaching \& Learning, 8(1), 87-98.

Jaya, S., R., S., \& Ermanto. (2013). Peningkatan keterampilan menulis puisi melalui media gambar siswa kelas $x .1$ sma negeri 2 kota sungai penuh. Jurnal Bahasa, Sastra Dan Pembelajaran, 1 (2), 87-95.

Kumar, V., \& Sultana, S. (2016). Integration of multimedia for teaching writing skills. CALL-EJ, 17(2), 57-86.

Lan, Y.-F., Hung, C.-L., \& HSU, H.-J. (2011). Effects of guided writing strategies on 
Atika Susanti et al., The Improvement in Poetry Writing Skills by Using Prezi...

students' writing attitudes based on media richness theory. TOJET: The Turkish Online Journal of Educational Technology, 10(4), 148-164.

Leo, S. (2010). Kiat jitu menulis dan menerbitkan buku. Jakarta: Erlangga.

Liu, P. (2016). Technology Integration in Elementary Classrooms: Teaching Practices of Student Teachers. Australian Journal of Teacher Education, 41 (3), 87-104.

Mcknight, K., Malley, K. O., Ruzic, R., Horsley, M. K., Franey, J. J., Bassett, K., ... Bassett, K. (2016). Teaching in a digital age: How educators use technology to improve student learning. Journal of Research on Technology in Education, 0(0), 1-18. https://doi.org/10.1080/15391523.2016. 1175856

Nugroho, I. R. (2014). Menjadi penulis kreatif. Yogyakarta: Notebook.

Nurgiyantoro, B. (2016). Sastra anak: Pengantar pemahaman dunia anak (Cetakan ke). Yogyakarta: Gadjah Mada University Press.

Omodara O D, Ed, M., \& Adu, E. I. (2014). Relevance of educational media and multimedia technology for effective service delivery in teaching and learning processes. IOSR Journal of Research \& Method in Education Ver. I, $4(2), \quad 48-51 . \quad$ Retrieved from www.iosrjournals.org

Putri, W. H., Ngatman, \& Joharman. (2017). Penerapan model think talk write (ttw) dengan media visual dalam peningkatan keterampilan menulis puisi pada siswa kelas $v$ SDN Kedungkamal. Kalam Cendekia, 5(2), 162-166.

Ramdhani, M. A., \& Muhammadiyah, $H$. (2015). The criteria of learning media selection for character education in higher education. Proceeding International Conference of Islamic Education: Reforms, Prospects and Challenges, 174-182.

Ritchie, T. D., Sedikides, C., \& Skowronski, J.
J. (2016). Emotions experienced at event recall and the self: Implications for the regulation of self-esteem, selfcontinuity and meaningfulness Emotions experienced at event recall and the self: Implications for the regulation of self-esteem, selfcontinuity a. Memory, 24(5), 577-591. https://doi.org/10.1080/09658211.2015. 1031678

Rusman. (2013). Belajar dan pembelajaran berbasis komputer. Bandung: Alfabeta.

Strasser, N. (2014). Using prezi in higher education. Journal of College Teaching \& Learning, 11 (2), 95-98.

Sunaengsih, C. (2016). Pengaruh media pembelajaran terhadap mutu pembelajaran pada sekolah dasar terakreditasi A. Mimbar Sekolah Dasar, $3(2)$,

183-190. https://doi.org/10.17509/mimbarsd.v3i2.4259

Tarigan, H. G. (2013). Menulis sebagai suatu keterampilan berbahasa. Bandung: Angkasa.

Taufiqurrahman, M., Untari, S., \& Yuniastuti. (2013). Pengembangan media CD pembelajaran berbasis prezi pada pokok bahasan globalisasi mata pelajaran PKN kelas IX MTSN Bangsal, Mojokerto. Jurnal FIS UM, 1(1), 1-12.

Utami, A. F., Djuanda, D., \& Aeni, A. Nu. (2016). Penerapan permainan bank kata dalam upaya meningkatkan keterampilan menulis puisi bebas. Jurnal Pena llmiah, 1 (1), 201-210.

Velloso, J. F. M. de L., Bastos, H. P. P., \& Macedo, S. da H. (2016). Prezi as a tool to assist in the development of linguistic abilities in english. Journal of Educational and Instructional Studies in the World, 6(4), 64-71.

Wahyudi, I., \& Hariani, S. (2014). Penggunaan media audio untuk meningkatkan keterampilan menulis puisi siswa kelas $\vee$ san sumberkembar mojokerto. Jurnal Penelitian Pendidikan Guru Sekolah Dasar, 2(3), $1-11$. 
Wu, T.-J., \& Tai, Y.-N. (2016). Effects of multimedia information technology integrated multi-sensory instruction on students' learning motivation and outcome. Eurasia Journal of Mathematics, Science \& Technology Education, 12(4), 1065-1074. https://doi.org/10.12973/eurasia.2016. 1552 a

Wulandari, N. A., \& Hakim, L. (2014). Perbandingan hasil belajar siswa melalui media pembelajaran prezi dengan powerpoint pada mata diklat akuntansi. Jurnal Mahasiswa UNESA, 3, $1-8$.

Zainurrahman. (2013). Menulis dari teori hingga praktik (penawar racun plagiarisme). Bandung: Alfabeta. 